\title{
EDITORIAL
}

\section{¿QUÉ ES LA EXCELENCIA EN MEDICINA?}

\author{
Wilson Bautista-Molano $M D, P_{H} D_{(C)}{ }^{2}$ \\ ${ }^{2}$ Docente Posgrados Médicos UMNG - Hospital Militar Central. Co-editor Revista Med \\ Facultad de Medicina UMNG. Reumatólogo Organización Sanitas Internacional
}

\begin{abstract}
Definir exactamente qué es excelencia en el área de la salud y más específicamente en Medicina constituye un reto. Desde su surgimiento, el ejercicio de la medicina ha estado basado en un gran humanismo con dedicación para tratar de aliviar o curar el padecimiento de los hombres. En este contexto juegan un papel fundamental no solo los sistemas de salud de cada país, sino también las Universidades, quienes son las encargadas de la formación de los recursos humanos en salud con los parámetros y exigencias que este proceso requiere. Su objetivo estratégico es la formación de profesionales con una sólida preparación científica, técnica y humanística.
\end{abstract}

El reto de las universidades en su empeño de formar médicos y otros profesionales de la salud, es aun superior pues se desarrolla en el contexto de la era de la globalización y de la generación de nuevas tecnologías. La Universidad Médica comprometida con la sociedad en la formación y perfeccionamiento de los recursos humanos en salud que necesita, es responsable junto con la formación científica de los estudiantes, de contribuir a la formación y desarrollo de valores que deben caracterizar a los profesionales de la salud en nuestro país, acorde con los principios éticos y humanísticos comprometidos con las necesidades epidemiológicas del país. Lo anterior redundará finalmente en la excelencia de la competencia y el desempeño de estos profesionales.

Por lo tanto, el ejercicio médico exige un compromiso ético orientado a proporcionar una asistencia de calidad, poniendo siempre por delante los intereses del paciente. La medicina moderna emplea hoy en día un nuevo modelo de práctica clínica: la medicina basada en la evidencia (MBE) frente al modelo tradicional, sustentado únicamente en la experiencia y en conocimientos empíricos. La MBE promueve acudir a los mejores estudios de investigación como herramienta de la clínica diaria. Surge en el siglo XX al entrar la estadística y los estudios epidemiológicos en la práctica médica y ha ido desarrollándose como herramientas que posibilitan la revisión y evaluación crítica de la literatura científica. El médico, además de saber ejecutar y realizar determinadas técnicas, debe tener acceso a esta información y ser capaz de interpretarla críticamente. $\mathrm{Si}$ a ello une la capacidad de interpretación y análisis crítico del contexto actual del paciente basado en los hallazgos clínicos, estará en la vía de lograr la excelencia. El buen médico utiliza ambas, maestría clínica y $\mathrm{MBE}$, porque ninguna basta por sí sola. La combinación de asistencia, investigación y docencia, y ejercer la medicina como una vocación de servicio es el camino que conduce a alcanzar la excelencia.

Los responsables de la Educación Médica Universitaria deben intentar dirigir la formación de los futuros médicos hacia la excelencia profesional.Se fomenta en ocasiones que los estudiantes se centren en obtener calificaciones satisfactorias, y no se hace énfasis en el aprendizaje. Así, estudian para aprobar y no para saber, alejándose enormemente de alcanzar el objetivo fundamental: la excelencia. Es por lo tanto necesario estimular la necesidad en los estudiantes de profundizar en los temas a través de libros, revistas y la utilización de bases de datos, es decir, de estudiar para saber, no solo para aprobar. Y en este asunto, la responsabilidad es conjunta y corresponde a estudiantes y profesores. La enseñanza debe estar fundamentada en la adquisición de competencias por parte del alumno durante el periodo de pregrado entendiéndose como tales al conjunto de conocimientos, habilidades y actitudes que el estudiante debe haber adquirido, de forma que le permita alcanzar una excelente práctica médica, adecuada al contexto social y epidemiológico en que se desarrollará. Es fundamental coordinar la relación entre las instituciones educativas (Facultades de Medicina) y las instituciones asistenciales (Hospitales y Clínicas), que intervienen en todas las fases de formación del Médico.

Las Universidades, y dentro de ella las Facultades de Medicina del país, tienen un desafío de importancia fundamental relacionados con la adecuada implementación de los actuales planes de estudio para dar cum- 
plida respuesta a los principios que rigen la excelencia en medicina. Este sistema involucra en primer lugar al profesor-docente, pero también y en mayor proporción al estudiante, que pasa de ser un sujeto pasivo a serlo plenamente activo, implicado en el auto-aprendizaje que le va a exigir mayor esfuerzo y dedicación. En este contexto la vocación de servicio adquiere mayor importancia y se relaciona con la actitud o disposición del individuo para desarrollar sus actividades, en este caso la inclinación del estudiante para dedicarse a todas las actividades que debe desempeñar como estudiante y posteriormente como médico. De igual forma, el docente a través de la integración del conocimiento y la generación de espacios académicos que fomenten temas de discusión y de debate que hagan participe al estudiante, permitirá focalizar el talento y las habilidades de cada uno de ellos para llegar al objetivo común que es la excelencia.
Finalmente, la dupla docente-estudiante debe ser dinámica, interactiva, proactiva y flexible. El profesor-docente debe conocer mejor a su estudiante y debe ser un orientador obligado no solamente del conocimiento, sino de las actitudes, aptitudes, habilidades y destrezas. Obviamente debe despertar, estimular y orientar la actitud investigativa y/o capacidad crítico-analítica del alumno; con miras a que una vez fuera de la universidad, esas herramientas adquiridas le faciliten la excelencia. Todo lo anterior debe estar enmarcado dentro del concepto de humanismo que debe incluir también aspectos culturales relacionados con las otras áreas del conocimiento, con el fin de mantener la integralidad del ser humano [no es bueno solo saber de medicina]. En definitiva, la sociedad exige un ejercicio médico de calidad y como actores del sistema todos estamos en la necesidad de conseguir la excelencia en el ejercicio profesional de la medicina. 


\title{
EDITORIAL
}

\section{THAT IS EXCELLENCE IN MEDICINE?}

\author{
Wilson Bautista-Molano $M D, P_{H} D(C)$ \\ Teaching Postgraduate Medical UMNG - Central Military Hospital. Co-editor of Journal UMNG \\ Medicine Faculty Med. Sanitas International Organization Rheumatologist
}

Define exactly what is excellence in the area of health and more specifically in Medicine is a challenge. Since its inception, the practice of medicine has been based on humanism with a great dedication to try to alleviate or cure the condition of men. In this context play a key role not only health systems in each country, but also universities, who are responsible for the formation of human resources in health parameters and demands that this process requires. Its strategic objective is to train professionals with a sound scientific, technical and humanistic preparation.

The challenge for universities in their efforts to train doctors and other health professionals, it is still superior as it takes place in the context of the era of globalization and the generation of new technologies. Medical University committed to society in the formation and development of human resources in health needs, is responsible along with the scientific training of students, to contribute to the formation and development of values that should characterize health professionals in our country, in accordance with the ethical and humanistic principles committed to the epidemiological needs of the country. This ultimately will lead to excellence in competence and performance of these professionals.

Therefore, medical practice requires an ethical commitment aimed at providing quality care, always putting the patient's interests. Modern medicine uses today a new model of clinical practice: evidence-based medicine (EBM) to the traditional model, based solely on experience and empirical knowledge. EBM promotes go to the best research studies as a tool for daily clinical practice. Surge in the twentieth century to enter the statistical and epidemiological studies in medical practice and has been developed as tools to enable review and critical evaluation of the scientific literature. The doctor, and know to run and perform certain techniques, should have access to this information and be able to interpret it critically. If it joins the playability and critical analysis of the current context of the patient based on clinical findings, is on track to achieve excellence. The good doctor uses both clinical and MBE master, because none alone is sufficient. The combination of care, research and teaching, and practice medicine as a vocation of service is the way that leads to excellence.

Managers of university medical education should attempt to direct the training of future physicians towards professional excellence. It sometimes encourages students to focus on obtaining satisfactory grades, and no emphasis on learning is done. Thus, studying to pass and not to know, away enormously from the fundamental goal: excellence in medicine. It is therefore necessary to stimulate the need for students to delve into topics through books, magazines and the use of databases, ie, to study to know, not just to pass. And in this case, liability is joint and is for students and teachers. Education should be based on the acquisition of skills by students during the undergraduate understanding as such the set of knowledge, skills and attitudes that the student must have acquired, so that allows achieving an excellent medical practice, appropriate to social and epidemiological context in which they develop. It is essential to coordinate the relationship between educational institutions (medical schools) and health care institutions (hospitals and clinics), involved in all stages of medical training.

Universities, and within medical schools in the country, have a critical challenge related to the proper implementation of existing curricula to respond adequately to the principles of excellence in medicine. This system involves first teacher - teacher, but also and in greater proportion to the student, who happens to be a taxable person to be fully active, involved in self-learning that is going to require more effort and dedication. In this context the service vocation becomes more important and is related to the attitude or disposition of the individual to perform their work, in this case the student's inclination to engage in all 
activities to be played as a student and later as a doctor. Similarly, teaching through the integration of knowledge and the generation of academic spaces that encourage discussions and debates that make the student participates, will focus the talent and skills of each of them to reach the common goal which is excellence.

Finally, the teacher - student duo should be dynamic, interactive, proactive and flexible. The teacher - teacher must get to know your child and should be a must not only knowledge, but also the attitudes, skills, abilities and skills counselor. Obviously must awaken, stimulate and guide the student's critical - analytical research attitude and / or performance; with a view to once out of college, he acquired those tools facilitate excellence. All this must be framed within the concept of humanism should also include cultural aspects related to other areas of knowledge, in order to maintain the integrity of the human being [is not good just knowing medicine]. In short, society demands a quality medical practice and as actors in the system are all in the need to achieve excellence in the practice of medicine. 


\title{
EDITORIAL
}

\section{¿EXCELÊNCIA EM MEDICINA O QUE É?}

\author{
Wilson Bautista-Molano MD, PhD (C) \\ Ensino de Pós-Graduação Médica UMNG - Hospital Militar Central. Co-editor da Revista Med \\ Faculdade de Medicina UMNG. Reumatologista, Organização Internacional Sanitas
}

\begin{abstract}
Definir exatamente o que é a excelência na área da saúde $e$, mais especificamente, em Medicina é um desafio. Desde a sua criação, a prática da medicina tem sido baseada no humanismo, com uma grande dedicação para tentar aliviar ou curar a doença dos homens. Neste contexto desempenham um papel fundamental, não só os sistemas de saúde em cada país, senão as universidades também, responsáveis pela formação de recursos humanos em saúde com treinamento e quesitos necessários pelo processo. Seu objetivo estratégico é formar profissionais com uma preparação científica, técnica e humanística de qualidade.
\end{abstract}

O desafio das universidades nos seus esforços para treinar médicos e outros profissionais de saúde, ainda é superior, uma vez que tem lugar no contexto da era da globalização $e$ da geração de novas tecnologias. O compromisso do ensino médico da Universidade na sociedade em formação $e$ aperfeiçoamento dos recursos humanos em saúde se precisando, é responsável, juntamente com a formação científica dos alunos, para contribuir na formação e o desenvolvimento dos valores que devem caracterizar os profissionais de saúde em nosso país, de acordo com os princípios éticos e humanistas comprometidos com as necessidades epidemiológicas do país. Esta última característica levará a excelência na competência e desempenho desses profissionais.

Portanto, a prática médica exige um compromisso ético que visa a prestação de cuidados de qualidade, sempre colocando os interesses do paciente. A medicina moderna utiliza hoje um novo modelo de prática clínica: medicina baseada em evidências (MBE) e o modelo tradicional, em base apenas na experiência e o conhecimento empírico. A primeira promove ir para os melhores trabalhos de pesquisa como uma ferramenta para a prática clínica diária. Surge no século XX pela introdução de estudos estatísticos e epidemiológicos na prática médica e foi desenvolvido como ferramenta para permitir a análise e avaliação crítica da literatura científica. $\mathrm{O}$ médico, além de executar e realizar certas técnicas deve ter acesso a esta informação e ser capaz de interpretá-la de forma crítica. Junto a capacidade de interpretação $e$ análise crítica do contexto atual do paciente com base nos achados clínicos, ele estará no caminho da excelência. O bom médico usa ambas, experiência clinica e a BEM, porque uma só não basta. $\mathrm{A}$ combinação de assistência, pesquisa e ensino, e praticar medicina como uma vocação de serviço é o caminho que conduz à excelência.

Os responsáveis da educação médica universitária devem tentar direcionar a formação de futuros médicos para a excelência profissional. Às vezes incentivam-se os alunos a concentrar-se na obtenção de notas satisfatórias, ficando afastados do objetivo fundamental: a excelência em medicina. Por isso, é necessário estimular a necessidade dos alunos para aprofundar temas através de livros, revistas e o uso de bancos de dados, ou seja, estudar para saber, e não apenas para aprovar. E, neste caso, a responsabilidade é conjunta com correspondência para estudantes e professores. O ensino deveria ser baseado na aquisição de competências pelo aluno durante a graduação, se entendendo no conjunto de conhecimentos, habilidades $e$ atitudes que o aluno deve ter adquirido, para atingir uma excelente prática médica, apropriada para o contexto social e epidemiológico em ser desenvolvido. É essencial para coordenar a relação entre as instituições de ensino (escolas de medicina) e instituições de saúde (hospitais e clínicas), envolvidos em todas as etapas da formação médica.

As Universidades e nelas as escolas médicas do país, tem um desafio fundamental relacionado com a implementação adequada de currículos atuais e princípios de excelência em medicina. Este sistema envolve primeiro o professor, mas também, e em maior proporção o aluno, deixando de lado a passividade para ser ativo envolvido na auto-aprendizagem que vai exigir mais esforço e dedicação. Nesta situação a vocação de serviço torna-se mais 
importante e está relacionada com a atitude ou disposição do indivíduo para desenvolver suas atividades, neste caso a inclinação do aluno de se envolver em todos os processos de estudante e depois como médico. Da mesma forma, o professor através da integração do conhecimento e a geração de espaços acadêmicos produzirão incentivos para a discussão e o debate com participação do estudante, focalizando o talento e as habilidades deles para o objetivo comum a excelência.

Por fim, a relação professor-aluno deve ser dinâmica, interativa, pró-ativa e flexível. O professor deve conhecer o seu estudante melhor e se comportar tais como um orien- tador obrigado não somente no conhecimento, mas nas atitudes, habilidades, capacidades e aptidões. Obviamente deve despertar, estimular e fazer orientação da atitude investigativa e/ou crítico-analítico do estudante; com vista a uma vez fora da faculdade, às ferramentas adquiridas facilitem sua excelência. $\mathrm{O}$ anterior no conceito de humanismo com inclusão de aspectos culturais relacionados em outras áreas do conhecimento, a fim de manter a integridade do ser humano [não é bom apenas saber medicina]. Em conclusão, a sociedade exige uma pratica medica de qualidade e todos como atores do sistema estamos obrigados em conseguir a excelência na pratica profissional da medicina. 